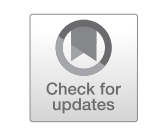

\title{
Claims for the Future: Indigenous Rights, Housing Rights, Land Rights, Women's Rights
}

Elke Krasny

In 2011, a year-long programme of cultural events and exhibitions celebrated Vancouver's 125th anniversary. On the occasion of this anniversary, the Audain Gallery, the Downtown Eastside Women's Centre (DEWC), and myself, as the gallery's visiting artist, entered into a collaboration that resulted in the research and exhibition project Mapping the Everyday. Neighbourhood Claims for the Future, with its articulations of situated indigenous and immigrant perspectives as they are contingent to the specific local histories and globalized neoliberal conditions. The purpose of this essay is to provide critical contextualization to the project and its making public of the claims put forward by women from the DEWC. Claims-making is understood here as a political act that constitutes subjects of rights. The politics of collectively formulating demands and making a public claim to them is at the heart of this project, as it tests what it means to perform citizenship under Vancouver's specific conditions as they are defined by coloniality and neoliberalism. My triple commitment to feminist political thought,

E. Krasny $(\bowtie)$

Academy of Fine Arts Vienna, Wien, Austria

(C) The Author(s) 2019

P. Hildebrandt et al. (eds.), Performing Citizenship, Performance

Philosophy, https://doi.org/10.1007/978-3-319-97502-3_8 
involved curatorial practice, and critical urban research provides the basis for the following feminist materialist and locationally specific close description and analysis of the Mapping the Everyday. Neighbourhood Claims for the Future project.

\section{VANCOUVER's 125TH ANNIVERSARY}

Founded in 1886, Vancouver's beginnings were, in fact, owed to the expansion of the Canadian Pacific Railway. This huge infrastructural investment effort was central to Canada's nation building, with the Canadian Pacific Railway's express purpose to 'physically unite Canada and Canadians from coast to coast." ${ }^{1}$ Even though most of the province of British Columbia (BC) remained unceded land, colonial legislation sought to ensure control of and power over the territory. 'In BC, aside from a small number of treaties on Vancouver Island (the $1850 \mathrm{~s}$ Douglas Treaties), and Treaty No. 8 in the northeast portion of the province, all of BC remains unceded Indigenous territories.'2 Today's Vancouver is located on the traditional unceded territory of the Skw $\underline{x}$ wú7mesh (Squamish), xwm $\theta \mathrm{kw}$ ỷ m (Musqueam) and s 1 ílw ta (TsleilWaututh) First Nations. Therefore, any historical anniversary celebration of the City of Vancouver would have had to first and foremost acknowledge the city's existence on 'stolen native land. ${ }^{3}$ It was only in 2014 , three years after the celebration of Vancouver's 125th anniversary that

Vancouver city council formally acknowledged (...) that the city was founded on land that still belongs to three First Nations communities (...). Vancouver's planning, transportation and environment committee unanimously passed a motion $[\ldots]$ that these territories were never ceded through treaty, war or surrender. ${ }^{4}$ (Coutts 2014)

Despite these complexly fraught conditions, the collaborators in the Mapping the Everyday. Neighbourhood Claims for the Future project decided to partake in the year of anniversary celebrations pointedly to make public and raise awareness for the claims for the future made by women throughout the history of the DEWC. Critically, this was done in order to counteract prevailing 'epistemic violence' and its resultant structural silencing (Spivak 1988, p. 280). 


\section{The Downtown Eastside Women's Centre and the Audain Gallery}

In what follows, I will provide contextualization for both of the involved institutions: the Downtown Eastside Women's Centre (DEWC) and the Audain Gallery. 'The DEWC is a self-initiated and self-organized space. (...) In many ways, it is an example of bottom-up feminist urbanism. In its day-to-day operation, the centre primarily represents Indigenous and older Chinese women, as well as other women of the Downtown Eastside community." ${ }^{5}$ On the occasion of Mapping the Everyday. Neighbourhood Claims for the Future, project partner Cecily Nicholson-a coordinator at the DEWC-described the founding moment via documents revealed through the research at the Centre as follows:

A friendly drop-in centre with social services and recreational programs available. Women, young and old, with or without children, are welcome. The centre has a homey atmosphere for women to meet one another, talk things over, or get information for specific needs. We encourage women to become aware of their own strength, and provide the resources to help themselves. We are five community workers, including a Native, and Chinese worker. (Nicholson 2011, email to the author)

Founded and incorporated in 1978, the Centre was established in the Downtown Eastside neighbourhood which, since the late 1950s, had witnessed

gradual marginalization of this community: the streetcars stopped running in the area; the main library moved to a location outside the Downtown Eastside; (...) The lack of affordable housing in other parts of Vancouver drove low-income people to the Downtown Eastside, as did the deinstitutionalization of thousands of psychiatric patients in the 1970s who found no other community willing to accept them (...) It is a culturally diverse community with 48 percent of its population representing visible minority groups, including residents of Chinatown, a large number of First Nations people from across the Americas, and many new immigrants to Canada. ${ }^{6}$

The neighbourhood is renowned for high rates of poverty, drug addiction, high levels of mental illness, prevalence of HIV-AIDS and the disappearance and murder of indigenous women. This district of Vancouver is 
invariably proclaimed as the 'poorest postal code in Canada' (Bitter 2011, p. 1). The Downtown Eastside area is marked by uneven development and massive gentrification pressures. There are high numbers of Aboriginal and homeless residents, many of them struggling with their vulnerabilisation and their everyday exposure to violence. At the same time, the neighbourhood boasts a long history of community activism - including groups such as the Western Aboriginal Harm Reduction Society, the Survival Sex Workers and the Vancouver Area Network of Drug Users-and also community centres, such as the Carnegie Community Centre or the Gathering Place. The Downtown Eastside Women's Centre is one such group, committed to support and activism.

The 1970s and the following decades witnessed a number of locally specific and complexly interrelated crisis transformations and emancipatory oppositional struggles. During this period, the Downtown Eastside saw deep structural urban transformations. These are Vancouver's local response to global currents of neoliberal urbanization-their capital-centric, developer-driven, and accumulation-oriented version. At the same time, the decades since the 1970s have given rise to a myriad of strong, vocal movements: indigenous political campaigns and claims, women's and feminist organizing, anti-poverty and housing struggles and a large number of different cultural, social and political mobilizations dedicated to producing 'oppositional consciousness' and instigating transformative change (Sandoval 1991). The DEWC is a safe space of everyday support to women in crisis under neoliberal urbanization conditions, and the Centre critically contributes to oppositional consciousness raising. Such support includes warm and nutritious meals just as much as legal or medical counselling, and healing practices like singing or poetry readings. The space allows for women to seek shelter from the violence on the streets just as much as it enables political subjectivization through the sharing of personal experiences, which leads to critical analysis and public claims-making.

Neoliberal urbanization and restructuring always take root locally. The everyday experiences of many of the women who are part of the DEWC are marked by the neoliberal globalized restructuring that reshapes the Downtown Eastside neighbourhood with rising property values and rising house prices driving out low-income and socially vulnerable long-time residents. 'Paradoxically, much of the contemporary political appeal to the "local" actually rests upon arguments regarding allegedly supra-local transformations, such as globalization, the financialization of capital, the 
erosion of the national state, and the intensification of interspatial competition' (Brenner and Theodore 2002, p. 341). The consequences of globalized neoliberal urban restructuring play out locally. The effects of this bear impact on questions of urban life and survival. It comes at the expense of lives and bodies made increasingly more vulnerable and exposed to structural dispossession and violence rooted in fierce competition over housing rights and access to the neighbourhood's resources.

In 2006, the Power of Women Group at the DEWC organized their first Women's Housing March, which has since taken place annually. On the occasion of the first march, the women put together a factsheet which included the following information:

The number of homeless people has doubled to approximately 2,174 people in 2005. (...) $30 \%$ of those who are homeless are indigenous people. Recent immigrants and refugees have been termed the 'hidden homeless', disproportionately living in crowded, sub-standard conditions. Given their uncertain legal status and lack of familiarity with Canada, they are the most likely to 'fall between the cracks of welfare' and housing provisions. Women are also among the 'invisible homeless', over-represented in shelters and transitional housing. ${ }^{7}$

Many other community groups, labour groups and organizations joined in the march. The research by the group also revealed that 'cuts to income assistance, legal aid, women's centres, attacks on women's advocacy and support services, lack of childcare support, rising costs of living and low-income work' have all had devastating impacts on women. According to the Greater Vancouver Regional District (GVRD) Homelessness Count in 2005, there has been 'an increase of $60 \%$ in the number of homeless women since the 2002 Count (...). ${ }^{\prime 8}$ In their researchbased activism and the arguments put forward, the Power of Women Group directly connect the structural victimization and increase in the numbers of homeless women to 'Indigenous Women Struggle against Colonialism, Violence, Racism and Poverty' as well as to 'Women Working in the Sex Trade."

The Power of Women group are a continuing part of long-term local women's activism. 1970s indigenous women's activism and struggle in Canada was provoked by the traumatic consequences stemming from the 1876 Indian Act. 'In Canada, the 1876 Indian Act redefined Indigenous identity in ways that disenfranchised and dispossessed large numbers of women (...)' (Huhndorf and Suzack 2010, P. 5). Therefore, the long-term 
implications of colonial dispossession and its legislation have proven to be one of the axes around which Aboriginal women's struggles and indigenous feminism in Canada pivot. As stated on the Canadian Indigenous Foundations website:

The Indian Act has been highly criticized for its gender bias as another means of terminating one's Indian status, thus excluding women from their Aboriginal rights. Legislation stated that a status Indian woman who married a non-Indian man would cease to be an Indian. She would lose her status, and with it, she would lose treaty benefits, health benefits, the right to live on her reserve, the right to inherit her family property, and even the right to be buried on the reserve with her ancestors. ${ }^{10}$

The dual oppression by patriarchy and by colonialism informed indigenous women's resistance and counter-oppression activism. 'In the 1970s, Aboriginal women began organizing to battle the discriminatory legislation.' ${ }^{11}$ The traumas of the 1876 Indian Act also include the imposition of sexual colonial politics and their long-term harmful impact on women's lives. 'The sexualization of Indigenous women, (...) an integral part of colonization, worsened the effects of governmental politics and left women particularly vulnerable to violence' (Huhndorf and Suzack 2010, p. 5$)$.

The factsheet assembled on the occasion of the first annual housing march links poverty and homelessness to the enduring structural impact of both the historical and the amended current versions of the Indian Act. 'Poverty amongst indigenous people stems from a legacy of colonial conquest. This has led to massive dispossession of traditional territories, lack of autonomy, and annihilation of cultures and traditions. (...) Almost $60 \%$ of Indigenous people now live in urban settings with the erosion of their land base. The majority of Aboriginal women - $72 \%$ - live in non-reserve urban areas.' 12

Many of the women at the DEWC are also actively involved with the annual Feb 14 Women's Memorial March. Between 1978 and 2001, over 60 women disappeared from the Downtown Eastside, many of them sex workers and Aboriginal. 'With over 60 women still missing from Vancouver's Downtown Eastside and the trial of William Pickton, the public has become increasingly aware of the issue of violence against sex workers, reflecting a larger pattern of violent assaults against women, particularly indigenous women. ${ }^{\prime 3}$ For years, the missing and murder cases of 
indigenous women and the trial of serial killer Robert William Pickton was mismanaged. The Women's Memorial March Committee raises awareness with regard to the systemic nature of violence that particularly targets sexualized and racialized women. They organize locally, nationally, and internationally. 'The first women's memorial march was held in 1991 in response to the murder of a Coast Salish woman on Powell Street in Vancouver. (...) Out of this sense of hopelessness and anger came an annual march on Valentine's Day to express compassion, community, and caring for all women in Vancouver's Downtown Eastside, unceded Coast Salish Territories.' ${ }^{14}$ The practice also extends to the national raising of awareness, with other memorial marches held across Canada, besides international activism. On the occasion of the 2012 memorial march, the organizers also set out to seek justice internationally. 'The Feb 14th Women's Memorial March Committee and DTES Women's Centre have recently made submissions under Article 8 of the Optional Protocol of the UN Committee on the Elimination of Discrimination Against Women, and are now seeking justice internationally. ${ }^{15}$

In a 2013 text-at once poem, political activism, and theory-Cecily Nicholson, quotes from the 'Communiqué' written by Idle No More and Defenders of the Land, a network of Indigenous communities in land struggle: 'Actively resist violence against women and hold a national inquiry into missing and murdered Indigenous women and girls, and involve Indigenous women in the design, decision-making, process and implementation of this inquiry, as [a step toward] initiating a comprehensive and coordinated national action plan. ${ }^{16}$

Even though the DEWC is a staunch supporter of women's struggles and women's activism, feminism and feminist practice remain contested territory for many indigenous women. 'As (...) women of colour, both scholars and activists, have long contended, feminism as a political movement and academic practice originated as a means to address the social problems of the white middle classes' (Huhndorf and Suzack 2010, p. 2). Feminism and indigeneity is a contested territory. '(...) the label “Aboriginal feminist” [is] fraught' (Green 2012, p. 16). Feminist practice therefore has to 'acknowledge the fraught historical relationship between Indigenous women and mainstream feminism as it opens discussions about the ways Indigenous women can construct a theory and practice specific to their interests' (Huhndorf and Suczak 2010, p. 5). Yet, it is not only the fraught relationship between feminism and indigeneity that such a project like Mapping the Everyday. Neighbourhood Claims for the Future 
has to be aware of and resistant to, but the equally fraught relationship between capitalism and mainstream feminism which Nancy Fraser has theorized extensively (Fraser 2013, pp. 209-226). 'The urgent task that she [Fraser] sets for feminists is to find the points where neoliberalism and feminism do not so easily converge, and to disrupt the easy passage of feminist critique into its neoliberal double. To her mind, this requires feminists to more fully reconnect their analyses to critiques of capitalist economic processes and with social movements' (Pratt 2013, pp. 120-121). The DEWC's activist research, the women's public manifestations, and their political activism on local urban, federal, cross-Canadian national, and internationally oriented global scale demonstrate that the DEWC connects their struggles not only to critiques of capitalist economic processes, but equally to its entanglement with the histories of colonialism. The DEWC women's investment, in oppositional consciousness raising and in solidarity alliance-building, aims for individual and collective transformative effects.

The Audain Gallery, where the Mapping the Everyday. Neighbourhood Claims for the Future exhibition took place, is part of the massive gentrification pressure marking the Downtown Eastside. Significantly, new university infrastructures just as much as contemporary art spaces, redefine image and status of entire neighbourhoods and contribute to rising property values and house prices. In the fall of 2010, the Simon Fraser University School for the Contemporary Arts and the Audain Gallery moved to a downtown campus located at the Woodward's Building. This is a landmark building attended with historical significance, struggles and occupation. Originally built in 1903 for the Woodward's Department Store, the building stood empty after Woodward's bankruptcy in 1993. In fact, it was the 2002 housing occupation-known under the name of Woodsquat - that actually triggered the redevelopment. In 2004, the city of Vancouver selected Westbank Projects/Peterson Investment Group as developers for the project; the architectural design work was assigned to Henriquez Partners Architects. It included market housing units as well as non-market housing units, and an addition to Simon Fraser University's downtown campus. Critical scholarship on gentrification has paid close attention to the contemporary art and higher education institutions as drivers of urban redevelopment and gentrification processes. Therefore, the specific situation of the Audain Gallery - in bringing together both the contemporary art and the campus component in the midst of a major process of gentrification-warrants doubt and provokes conflicts regarding the politics and the ethics of alliance-building with its neighbours. 
Sabine Bitter, the Audain Gallery's then director, stated that due to Simon Fraser University's downtown move, 'questions of gentrification, representation, site-specificity, and research ethics have become crucial' (Bitter 2011, p. 1).

\section{Claims for the Future}

It is against these complex conditions wrought by the structural effects of historical colonialism and present-day neoliberal urbanization dynamics that the women at the DEWC have sustained their everyday survival practices and their long-standing commitment to activism regarding indigenous rights, housing rights, land rights and women's rights. The newsletters the Centre has issued since its inception are a repository, an archive of the women's work and, most importantly, of their claims. Following my suggestion to work with the Centre's history in order to demonstrate their persistence and their work towards futurity-which can be best understood from their claims-a series of workshops with an ad hoc group ${ }^{17}$ at the DEWC provided the research necessary to map the claims from the newsletters, to select them and organize them chronologically for the exhibition. The list of claims were transformed into a text-based wall installation spanning the Audain Gallery's exhibition space as a horizon line. This key feature of the exhibition consisted of the extensive list of claims organized chronologically, going around the walls, in several lines of text on top of each other. All the claims that were presented are included in this text, so they can be read, and heard, again:

Take Back the Night (1979-)

Stop Violence Against Women (1980-)

Our Hearts Go Out (1980-)

In Loving Memory (1980-)

Battered Women's Support Group (1980-)

Banner Making Party (1982)

You are Not Forgotten (1982)

Create a Powerful Force of Change (1984)

East Meets West Social Party (1984)

Know Your Rights workshop (1984)

Hope for the Family (1984)

Support One Another (1985)

Role Models (1985) 
Positive Parenting (1985)

Working Women's Drop-In - Ring Buzzer (1985)

A Chance for Women (1985)

We are the Seers, the Healers, the Warriors (1985)

The Common Woman is as Common as a Common Loaf of Bread and Will Rise (1985)

Gather Together (1986)

Free Soup and Bannock (1986)

Take Back Your Power (1986)

Ongoing Social Action (1986)

No drugs or alcohol in the Centre. We don't want a reason for the cops to come here! (1986)

See Some of the Strengths That You Did Not Know You Had (1985)

*All Women Band* A Benefit Performance-all proceeds to raise money for musical instruments for our Sisters in Oakalla. Women's Event-At the Centre. Free if you are broke

Condoms, street Talk and Badtrick Sheets Available (1986)

Gather Together (1986)

Take Back Your Power (1986)

Share Your Memories (1987)

Decrease the Grief (1987)

Bad Trick Sheets (1987)

Assertiveness with a Beat (1987)

Spruce You Up! Tie-dye to 50s music (1987)

Festival for Foods Parade (1987)

Grassroots Fundraising (1987)

Information and Support Sharing (1987)

No Way to Live (1988)

Take the Next Step (1988)

We Announce Our Solidarity (1988)

The Needs of Women Come First (1988)

Welfare Rates Under Attack (1988)

Tenants Rights Workshop (1988)

Becoming yourself through writing (1988)

Fight for Welfare Rights (1989)

Women's Right to Choose (1989)

Women's Forum (1989)

Willing and Able (1989)

No Homophobia (1989) 
No Racism (1989)

Projects Collective (1989)

Fight City Hall (89-present)

On December 19th, approximately 2000 people gathered at City Hall to protest rising rents and growing homelessness (1989)

Red Road Warriors (1989)

Menopause Support Group (1989)

Clean and Sober Group meeting (1989)

Recovery (1989)

Family Clean and Sober Group (1989)

Please do not take things that are not yours (1989)

Hold Your Ground (1990)

Sleeping Hummingbirds (1990)

We've Survived the Long Winter (1990)

Always Play Safe (1990)

Impossible Takes a Little Longer (1990)

Their Spirits Live Within Us (1990 -)

Justice for Missing and Murdered Women (1990s)

Justice for Residential School Survivors (1990)

We are also always in need of clothes for women (1990 -)

Campaign to Get Welfare Raised (1991)

Reclaiming Your Power (1991)

Aboriginal Celebrations and Ceremonies (1991)

Sisters in Spirit (1990 -)

The February 14th Women's Memorial March Committee (1992 -)

We are committed to justice (1992 -)

Tools for Change (1994)

A Safe Place for Women (1994)

Grief and Loss Support (1995)

Visualizing Workshops (1995)

Stop the War on the Poor! (1996)

Raise the Rates (1998)

Bad Date Sheets (1998)

Psychiatric Day Program (1999)

Healing Circle (1999)

Make a Wild Woman Out of You (1999)

Popular Education (1999-2003)

End Legislated Poverty (1999-2004)

The Learning Group (2000-02) 
Learn how to make something from nothing (stone soup) (2000)

Today in One Circle (2001)

Welcome Home (2001)

We Must Stand Together for Peace Justice, Freedom and Equality (2001)

Honour our Sisters and Grandmothers (2001)

Join Us Women (2001)

Sisters Resist (2001)

Breaking the Silence (2001)

Positive Body Images (2001)

Appropriate Programming (2001)

There is joy in the struggle (2002)

There is joy in the struggle (2002)

Outings Rock Our World (2003)

University Access: Institute of Indigenous Government Canada's First Nations College, in Partnership with the DEWC - Tuition Free (2003)

Stop Police Violence (2003)

DTES, I Love (2004)

Stop Attacks on Women (2004)

Rise Up (2005)

Love and Support (2005)

Imagine the woman who honours the face of the goddess in her own changing face (2005)

Fight to get power back into women's hands at the Women's Centre (2005)

Donations Committee asking for your help (2005)

Pow Wow (2005)

Celebrate a New Beginning (2006)

Build Community (2006)

[first annual] Women's Housing March (2006)

Our Own Voices: of Pain and Hope (2007)

Vigil and March to Honour Women (2007)

Stop All Forms of Violence Against Women: End Patriarchy! (2007)

Power of Women (2007)

Safe Housing for Women (2007)

An Open Letter to Mayor Sam Sullivan and City Council from Women in the Downtown Eastside (July 2, 2007)

DTES Community Meeting at DEWC - Men Welcome. Open to All Concerned DTES Residents and Community Members (2007)

March for Women's Housing and March Against Poverty! Elders, Youth, Men Welcome Bring Drums and Your Friends (2007) 
Stop Child Apprehension, Support Mothers (2008)

We Demand an Inquiry into the Missing Women (2008)

People Are Dying (2008)

Social Housing, Healthcare and Childcare Now! (2008)

No More Evictions and No More Condos! (2008)

Stop Criminalizing the Poor (2008)

End Global Hunger and Poverty (2008)

Affordable and Safe Housing Now! (2009)

Stop Ticketing and Arrests Under Project Civil City (2009)

Fight Rapid Hotel/SRO Closures and Evictions (2009)

Stop Police Brutality (2009)

Housing Now (2010)

In Our Own Voices (2010)

No Olympics on Stolen Native Land! (2010)

People Before Olympic Profits (2010)

Survival, Strength, Sisterhood: Power of Women in the Downtown (2010)

Our Lives, Our Voices: Downtown Eastside women find healing through narrative (2010)

Respect Your Elders (2011)

We will be marching to demand action on women's safety (2011)

Women's Coalition of the Downtown Eastside: Women's Safety 24/7 Women's Coalition of the Gone but not Forgotten (2011)

Downtown Eastside is a newly formed network of women-serving organizations and women's groups in the Downtown Eastside of Vancouver, Coast Salish Territories (2011)

Stop the Pantages Development (2011)

Boycott Sequel 138 (2011)

Gentrifuckation (2011)

Housing for All (2011)

Social Housing, Child Care and Health Care for All! (2011)

No more evictions and no more gentrification in the Downtown Eastside! (2011)

Stop criminalizing the poor! (2011)

DTES is Not for Developers (2011)

Many Paths of Our Resistance (2011)

Participant Groups in the Missing Women's Inquiry Pressure Premier Clark to Ensure Access and Justice (2011)

Committee Announces Non Participation in Sham Inquiry (2011) 


\section{CONCLUSION}

Anniversary celebrations held by cities form part of the official rituals and political routines; they simply reinforce established hegemonic historical claims. However, through the collaboration between the women at the DEWC, the Audain Gallery and myself, claims to the future by indigenous and mostly elderly Chinese immigrant women active at the centre were presented and given attention within Vancouver's 125th anniversary celebrations. This action was made against a backdrop of the sheer complexity of fraught conditions surrounding the anniversary celebration and Vancouver's history, critically given the fact that Vancouver today remains as unceded Coastal Salish territory. When such claims form part of commemoration practices, they become constitutive to resistant historical narratives just as much as they have to be moved forward towards ensuring future change. 'The claims and demands, both current and historical, address issues of poverty, violence and insecurity, social exclusion, the deferral of rights, and the legacy of colonialism.(...) They are also expressions of conviviality and solidarity between women, between women and their neighbourhoods, and between the women of the Centre and their global context' (Krasny 2011, p. 2). Claims for the future imply that there is, in fact, a future to be claimed. Therefore, it is important to consider the act of putting forward claims as an act towards futurity. As the women collectively voice their claims, they enact modes of political subjectivization. Through their claims-making they perform their rights to and their rights of citizenship.

\section{Notes}

1. Canadian Pacific Railway, date accessed January 2, 2017.

2. No2010, date accessed January 2, 2017.

3. No2010, accessed January 2, 2017.

4. Coutts, 2014, accessed January 2, 2017.

5. Art and Education Net, date accessed January 2, 2017.

6. Learning Exchange, date accessed January 2, 2017.

7. Carnegie Centre, date accessed January 2, 2017.

8. Carnegie Centre, date accessed January 2, 2017.

9. Carnegie Centre, date accessed June 5, 2016.

10. Indigenous Foundations, date accessed January 2, 2017.

11. Indigenous Foundations, date accessed January 2, 2017.

12. Carnegie Centre, date accessed January 2, 2017. 
13. Carnegie Centre, date accessed January 2, 2017.

14. Women's Memorial March, date accessed January 2, 2017.

15. Women's Memorial March, date accessed January 2, 2017.

16. Due to Injuries, date accessed January 2, 2017.

17. This ad hoc group included Stella August, Muriel Brunelle, Dalannah Gail Bowen, Shurli Chan, Pat Haram, Audrey Hill, Suzanne Kilroy, Karen Lahay, Terri Marie, Joan Morelli, Ramona, Sandra, Sara Dell, Sue Lee, Stirling Sexton, Beatrice Starr, Debbie Ventury, Bernice Verde and Deanna Wong (translation).

\section{REFERENCES}

Art and Education Net. http://www.artandeducation.net/announcement/mapping-the-everyday-neighbourhood-claims-for-the-future/. Accessed 2 Jan 2017. Bitter, S. 2011. Mapping the Everyday. Neighbourhood Claims for the Future. In Mapping the Everyday: Neighbourhood Claims for the Future, ed. Audain Gallery., Brochure Published on the Occasion of the Exhibition Held 17 November 2011-25 February 2012. Vancouver: Simon Fraser University.

Brenner, N., and N. Theodore. 2002. Spaces of Neoliberalism: Urban Restructuring. Oxford: Wiley-Blackwell.

Canadian Pacific Railway. http://www.cpr.ca/en/about-cp/our-history. Accessed 2 Jan 2017.

Carnegie Centre. http://www.carnegie.vcn.bc.ca/womens-housing-march-drawslarge-support?Func=previousthread\#id l uxppukq5vsewxuqfjhcjq. Accessed 2 Jan 2017.

Coutts, M. 2014. Vancouver Council Formally Acknowledges City Was Built on Unceded First Nations Territory. Daily Brew, June 26. https://ca.news.yahoo. $\mathrm{com} /$ blogs/dailybrew/vancouver-council-formally-acknowledges-city-builtunceded-first-220234880.html. Accessed 2 Jan 2017.

Due to Injuries. http://duetoinjuries.com/response-cecily-nicholson/. Accessed 2 Jan 2017.

Fraser, N. 2013. Feminism, Capitalism and the Cunning of History. In Fortunes of Feminism. From State-Managed Capitalism to Neoliberal Crisis, 209-226. London/New York: Verso.

Green, J. 2012. Making Space for Indigenous Feminism. Winnipeg: Fernwood Publishing.

Huhndorf, Shari M., and Cheryl Suzak. 2010. Indigenous Feminism: Theorizing the Issues. In Indigenous Women and Feminism. Politics, Activism, Culture, ed. C. Suczak, S.M. Huhndorf, J. Perreault, and J. Barman, 1-20. Vancouver: UBC Press.

Indigenous Foundations. http://www.Indindigenousfoundations.arts.ubc.ca/ home/government-policy/the-indian-act.html. Accessed 2 Jan 2017. 
Krasny, E. 2011. Mapping the Everyday. Neighbourhood Claims for the Future. In Mapping the Everyday: Neighbourhood Claims for the Future, ed. Audain Gallery, Brochure Published on the Occasion of the Exhibition, Held 17 November 2011-25 February 2012. Vancouver: Simon Fraser University.

Nicholson, C. 2011. E-mail Correspondence with the Author.

No2010. http://www.no2010.com/no-olympics-on-stolen-land/. Accessed 2 Jan 2017.

Pratt, G. 2013. Unsettling Narratives: Global Households, Urban Life and a Politics of Possibility. In Rethinking Feminist Interventions into the Urban, ed. L. Peake and M. Rieker, 108-124. London/New York: Routledge.

Sandoval, C. 1991. Feminist Theory Under Postmodern Conditions: Toward a Theory of Oppositional Consciousness. Santa Cruz: University of California.

Spivak, G.C. 1988. Can the Subaltern Speak? In Marxism and the Interpretation of Culture, ed. C. Nelson and L. Grossberg, 271-313. Urbana: University of Illinois Press.

Suczak, Cheryl, S.M. Huhndorf, J. Perreault, and J. Barman, eds. 2010. Indigenous Women and Feminism. Politics, Activism, Culture. Vancouver: UBC Press.

Women's Memorial March. https://womensmemorialmarch.wordpress.com. Accessed 2 Jan 2017.

Open Access This chapter is licensed under the terms of the Creative Commons Attribution 4.0 International License (http://creativecommons.org/licenses/ by $/ 4.0 /$ ), which permits use, sharing, adaptation, distribution and reproduction in any medium or format, as long as you give appropriate credit to the original author(s) and the source, provide a link to the Creative Commons licence and indicate if changes were made.

The images or other third party material in this chapter are included in the chapter's Creative Commons licence, unless indicated otherwise in a credit line to the material. If material is not included in the chapter's Creative Commons licence and your intended use is not permitted by statutory regulation or exceeds the permitted use, you will need to obtain permission directly from the copyright holder.

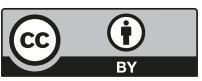

